\title{
12. New Zealand war correspondence before 1915
}

\section{ABSTRACT}

Little research has been published on New Zealand war correspondence but an assertion has been made in a reputable military book that the country has not established a strong tradition in this genre. To test this claim, the author has made a preliminary examination of war correspondence prior to 1915 (when New Zealand's first official war correspondent was appointed) to throw some light on its early development. Because there is little existing research in this area much of the information for this study comes from contemporary newspaper reports. In the years before the appointment of Malcolm Ross as the nation's official war correspondent, New Zealand newspapers clearly saw the importance of reporting on war, whether within the country or abroad and not always when it involved New Zealand troops. Despite the heavy cost to newspapers, journalists were sent around the country and overseas to cover conflicts. Two types of war correspondent are observable in those early years-the soldier journalist and the ordinary journalist plucked from his newsroom or from his freelance work. In both cases one could call them amateur war correspondents.

Keywords: conflict reporting, freelance journalism, war correspondents, war reporting

\section{ALLISON OOSTERMAN}

AUT University, Auckland

7 HIS ARTICLE is a brief introduction to New Zealand war correspondence prior to 1915 when the first official war correspon-

1 dent was appointed by the government. The aim was to conduct a preliminary exploration of the suggestion, made in The Oxford Companion to New Zealand military history (hereafter The Oxford Companion), that New Zealand has not established a strong tradition of war correspondence (McGibbon, 2000, p. 578). The book claimed most war reporting had been 
sponsored by the state and that New Zealand war correspondents had been noted 'for their journalistic competence rather than for literary talent'. (This third claim has not been examined in this study.) The book devoted a mere seven sentences to New Zealand war correspondence prior to World War I. The Oxford Companion's main concern, however, was with the campaigns and battles which involved New Zealand (p. xii). It does not consider wars with no New Zealand involvement but nevertheless to which New Zealand journalists were sent. It seemed appropriate to test whether there was any tradition of war correspondence before 1915. This study shows that newspapers were enterprising in sending journalists to various conflicts to provide a New Zealand view for their readers. The state did not sponsor journalists before 1915. What was also clear was that the conflicts mentioned in this article were considered by the newspapers to be wars and the journalists covering them were 'war correspondents'. Modern interpretations might contest this.

Journalists before 1915 were sent to cover wars within New Zealand but also in Samoa, South Africa and China. Newspapers were not just concerned with conflicts which involved the country's own soldiers. They sent journalists to cover the turbulent events in Samoa in 1899 and in China in 1901 where New Zealand troops were not involved. Newspapers often joined together to send a journalist overseas-one way of reducing costs. More is known about the joint efforts of The Press, the Otago Daily Times, Evening Post and the New Zealand Herald in this regard, but future research will probably show that other big papers of the pre-war years such as the Auckland Star, and the New Zealand Times also employed war correspondents.

The Merriam-Webster online dictionary defines the word 'tradition' in two ways that are relevant to this study; as an 'inherited established, or customary pattern of thought, action, or behaviour (as a religious practice or a social custom)' or 'a belief or story or a body of beliefs or stories relating to the past that are commonly accepted as historical though not verifiable' and as 'the handing down of information, beliefs, and customs by word of mouth or by example from one generation to another without written instruction' (Merriam-Webster dictionary online, 2007). The contention of this study is that a tradition of New Zealand newspapers appointing journalists to act as war correspondents for short periods in different wars had been established prior to 1915. 


\section{The New Zealand Wars 1845-1872}

Not much is known about early New Zealand journalists' views on war correspondence but there was one indication to be found in a leading article of Dunedin's Otago Daily Times on 28 August 1900 under the heading War correspondents. The leader noted that war correspondents at the turn of the century were now regarded as a 'necessary adjunct to a modern newspaper' but it was rather dismissive of the need to cover the conflict between Māori and white settlers.

In the early days, when war was waged in various parts of the North Island against the Māori, there were little or no opportunities for the war correspondent and recent enterprising journals in this colony devoted more attention to exploration and the opening up of new country for settlement than to warlike subjects. (War correspondents, 1900)

For New Zealand's oldest daily newspaper, the New Zealand Wars, or as they were called at the time, the Māori Wars or Māori War (The Māori War, 1860; The Māori Wars, 1906), must have slipped its memory if it could consider the Parihaka campaign of 1881 as 'the first real opportunity afforded in this colony to the war correspondent'. Perhaps this was because fighting occurred mainly in the North Island. Edward T. Fricker represented the Otago Daily Times at Parihaka, where the passive resistance of Māori to the confiscation of their land was crushed by Government forces.

Northern newspapers certainly sent journalists to cover the campaigns of the New Zealand Wars. A notable correspondent was William Morgan, who worked out of Drury and sent reports to the Daily Southern Cross and occasionally the London Weekly Review, over a period of about six months (Morris, 1963, p. 7). He is not mentioned in The Oxford Companion. As a young man, Morgan began a journal a few days after leaving England in 1852 . This journal forms the basis of the many published accounts he wrote during the war in the Franklin area from July 1863. His despatches were often published in other New Zealand newspapers.

The Daily Southern Cross had other correspondents writing about the war, such as Charles Williamson. He covered the Waikato and Tauranga campaigns often with Howard Willoughby, the special correspondent representing the Melbourne Argus and Australia's first war correspondent (Local and general, 1883; Dictionary of Australian Biography, 2010). As well, the editor, 
Robert James Creighton, spent some time in the field as a correspondent, according to Guy Scholefield (Scholefield, 1958, p. 78). The opposition paper in Auckland, The New Zealander, also fielded a war correspondent, albeit a volunteer one, John Sheehan, who later became Minister of Native Affairs (Our public men, 1878).

The Oxford Companion also cited other journalists, for example, G.W. Woon, the owner of the Taranaki Herald, saying he should bear the title of New Zealand's first war correspondent. 'As a member of a volunteer unit, he produced a journal of events based on the fighting in Taranaki from 1860 to 1861' (p. 578). Guy Scholefield, journalist and author of Newspapers in New Zealand (1958), recorded that Woon served his apprenticeship in the New Zealander's Wellington office before heading for Taranaki to become the nominal editor of the Taranaki Herald. He bought the paper in 1854 and was the editor for most of the time from then to 1867 (pp. 129-131). The regular Journal of Events he published from 1860 at the commencement of the Waitara conflict was seen by Scholefield as a 'valuable source for the history of that period', since Woon was a member of the Rifle Volunteers 'and knew what was passing'.

Other correspondents to cover the New Zealand Wars, says The Oxford Companion, were W.D. Campbell (Lyttelton Times), Gustavus von Tempsky (Daily Southern Cross) and John Featon, who published a history of the Waikato campaign in 1879 (Featon, 1879). One could also point to Charles Otto Montrose who made his mark with letters from the front when he was a foot soldier with one of the regiments of the line during the wars. He later became a subeditor of the Auckland Star under T. W. Leys (Untitled, 1907). There are probably other men (and they were almost always men) as yet unresearched who covered the wars. A common feature of war correspondence of the time appeared to be journalists combining their newspaper work with their own military activity. That is certainly true of Woon, von Tempsky and Montrose.

\section{Other inspirations prior to 1899}

Many New Zealanders in the late 19th century were inspired by the exploits of renowned war correspondents from Britain and elsewhere. Before the New Zealand Wars of the 1860s, William Russell, of The Times, with his despatches from the Crimean War (1853-1856) (Russell, 1855), was highly regarded. Later, such journalists as Archibald Forbes, who covered the 
Franco-Prussian War, in the early 1870 s and the Russo-Turkish campaign of 1877 (Is the war correspondent doomed?, 1904; Lovelace, 1978; Ward, 1907-1921) and Bennett Burleigh of the Glasgow Daily Mail were published widely back in New Zealand.

As well, the country was often visited by war correspondents on lecture tours. Probably the most eagerly awaited was Forbes, who arrived in Invercargill to give his first lecture to a full house on November 28, 1882 (Archibald Forbes in New Zealand,1882). Another war correspondent to visit was Howard Vincent, the special war correspondent for the Daily Telegraph with the British army in the Danube during the Russo-Turkish War of 1877 (Mr Howard Vincent, 1884). He toured the country in October 1884. He was followed a year later by George Augustus Sala, of The Telegraph (Hatton, 1885; Passing notes, 1885; Sala, 1885). Phil Robinson, the war correspondent with the Daily Chronicle visited New Zealand in 1888 and was extensively reported while in the country (A celebrated war correspondent, 1888; Experiences of a war correspondent, 1888; An interview with Mr Phil Robinson, 1888) as was his very messy divorce late in May 1889 and his arrest in Cuba as a spy (Judicial separation, 1889; More pressmen arrested, 1898; Phil Robinson's divorce case, 1889; Phil Robinson and his troubles, 1889).

Next to make a speaking tour was David Christie Murray, war correspondent of the London Times (Looking at war, 1890; Mr David Christie Murray, 1890) followed by H. M. Stanley, war correspondent in Abyssinia and finder of Livingstone (The Stanley lectures, 1892). The final war correspondent of note to tour the country prior to the Samoan troubles and the South African War was Frederic Villiers, the veteran correspondent of the Standard who witnessed the taking of Khartoum 10 years earlier and who toured New Zealand in 1895 (A great war correspondent, 1985; Mr Villiers on New Zealand, 1895).

The New Zealand press seemed particularly interested in the dangers correspondents faced in the execution of their assignments. Papers ran numerous stories of arrests, expulsions and deaths of correspondents on overseas battlefields. Certainly war correspondents in these days were news in themselves. The 'romance' of the war correspondent was often mentioned and the decline in the 'romance' was often mourned when it came to considering the role of the journalist in World War I.

We no longer hear much of war correspondents at the front. Behind the battle front is the new and more appropriate phrase. The romance 
of the war correspondents' business has gone with its risks. (Untitled, 1915, p.10)

\section{The Samoan 'troubles' 1899}

The Oxford Companion made no mention of the war correspondence conducted during this tumultuous period in Samoan history, because it was not a conflict the New Zealand military was involved in, despite offers by the New Zealand Government of 500 troops and two Maxim guns (The Samoan situation, 1899). At least three journalists were sent to Samoa. One of these was Malcolm Ross, the journalist writing for the Otago Daily Times and The Press on contract, who, when Parliament was not in session, was free to choose his assignments. He asked to go to Samoa saying he estimated that costs would be well under $£ 50$. It was agreed that the Otago Daily Times would share the expenses of the correspondent with The Press and the Evening Post (Board of directors minute book 1895-1901).

The background to this conflict was covered in a previous article published in Pacific Journalism Review (Oosterman, 2008). Suffice it to say that although New Zealand troops were not involved, New Zealand considered this a war over claimants to the Samoan throne. Certainly the New Zealand papers were calling it the Samoan War. (The Samoan war-attitude of the powers, 1899; The Samoan war-sharp fighting with the rebels, 1899). The three major powers of Germany, Britain and the US were involved and armed intervention took place. Ross was sent to Samoa because of New Zealand's interest in the island nation but also, one suspects, because two other large New Zealand dailies, the New Zealand Herald and the Auckland Star, had sent or were about to send journalists to Apia. The NZ Herald reporter was Fred Carr Rollett and he was in Samoa when Ross arrived. Rollett was made the agricultural editor of the Auckland Weekly News and NZ Herald in 1898 (Obituary: F. Carr Rollett, 1931). He was referred to in Ross's first dispatch (M. Ross, 1899c). The other journalist was James Cowan, acting for the Auckland Star, who like Ross 'had a late look-in' to the Samoan situation (Untitled, 1903). Cowan, who was fluent in Māori, also wrote a highly regarded official military history of the New Zealand Wars (McGibbon, 2003).

Ross appeared able to work and write at will with very few restrictions. His first despatch was published on February 14, 1899 in summarised form in the Evening Post, and on the following day in the Otago Daily Times and 
The Press having been sent from Apia on February 8 on the steamer Mariposa to Auckland from where it was then telegraphed to each subscribing paper (M. Ross, 1899c, 1899e). It took about five days for the steamer to get from Apia to Auckland, so the news was still fairly fresh when it arrived in New Zealand. This first batch of stories was run over the next few days. He apparently teamed up with Rollett to get some of the interviews with the main actors in the drama, from the German, British and American authorities to the Samoan chiefs on both sides of the conflict. The Press story ran to more than 10,000 words over six columns and was continued the next day with a further 5,000 words and the following day with around 3,500 words. By early May Ross was winding down his despatches as an armistice was declared. His final report from Samoa was published in the Otago Daily Times on May 20 and ran over two and a half columns or around 5,500 words. Rollett and Cowan were running full despatches as well from Apia during the 'troubles' and in fact, Rollett appeared to have stayed on after Ross had left. It was not until November 10,1899 that New Zealand heard by cable that the three commissioners had agreed on a settlement for Samoa (The Samoan settlement, 1899). New Zealand newspapers expressed their disappointment at partition but by now their attention had been diverted to another theatre of war-South Africa.

\section{The South African War 1899-1902}

With a second war looming between the Transvaal and Great Britain in 1899, George Fenwick of the Otago Daily Times was writing in July to the principals of the NZ Herald, NZ Times and The Press about the possibility of jointly sending a war correspondent to South Africa should war break out. Fenwick put forward as a candidate, Major D. M. Kennedy, who had spent four and a half years in South Africa. He estimated the cost for a correspondent for six months to be from $£ 380-£ 400$ (Fenwick, 1899-1902). Nobody was expecting the war, if it occurred, to last very long. On October 11, war began and the first contingent of New Zealand soldiers was about to leave, so the newspaper editors hastened to pick their representatives.

The Auckland Star leader writer, possibly editor T. W. Leys, hinted at what readers might be looking for from these correspondents at the 'seat of war'.

When we take up the papers to read the war news it will be a minor matter how the fortune of battle has turned, compared with the least information as to how our boys have stood their ground. It will not be 
of General This or Major That we shall be most anxious to hear, but of names familiar to our mouths as household words - men of Auckland, Waikato, Coromandel and the rest. (Untitled, 1899a, p. 4)

Mentioned in that same paper of October 9 was Private Claude Jewell, 27, second class shot, of the Auckland Mounted Rifles, who was among the Auckland contingent of volunteers being farewelled before embarking for Wellington. Jewell was to make his name writing despatches from South Africa for the Auckland Star, thus continuing the tradition of soldier journalists begun during the New Zealand Wars. In a mirror of the Samoan conflict New Zealand had offered troops to support Britain in South Africa in September but this time the offer was accepted and troops left the country on October 21 (Crawford, 2000, pp. 59-63). This was the first time in the country's history that New Zealand soldiers had left home to fight overseas. New Zealand contributed 10 separate contingents of around 6,500 volunteers. The Observer noted in November 1899 that two Australian pressmen, Donald Macdonald and W. J. Lambie, had been sent to South Africa to write up the war for the big dailies. Other journalists to cover the war for Australia were bush poet and journalist A. B. 'Banjo' Paterson and A A G 'Smiler' Hales. The Observer was particularly scathing about what the New Zealand dailies might do and how tight-fisted they were inclined to be when appointing and supporting their war correspondents.

The cheapest thing in the 'special war correspondent' line is alleged to have been accomplished by a big New Zealand daily. Directly it heard that the Government was despatching three tailors away in the SS Waiwera to complete the contingent's uniform on the trip to the Cape, it bespoke the literary services of one of the snips. Of course he will be paid according to measure and is expected to turn out slops of stuff. It may be shoddy but still it will sell the paper all right. (Untitled, 1899b, p. 6)

The Observer was not far off the mark as regards the newspapers' feelings about the expense of sending correspondents overseas. The minutes of the board of the Otago Daily Times recorded the decisions made regarding New Zealand newspapers sending correspondents to South Africa (Board of directors minute book 1895-1901). In September the board had discussed whether 
to send a correspondent and noted that it had received an offer from Major Kennedy to do the job. However board members believed the cost of sending a special correspondent to the Transvaal would turn out to be too expensive. They decided to try and arrange with one of the Melbourne papers for the right to use their war correspondence. At the end of September, George Fenwick wrote to the editor of the Cape Times to arrange for correspondence to be sent to Dunedin in the event of war breaking out. This was believed by board members to be more satisfactory than using any of the Melbourne papers or than sending their own man. However by mid October the big three papers, the Otago Daily Times, The Press and the NZ Herald were again in talks about jointly sending correspondents to South Africa. The latter two papers pressed to send two people and picked J. Elder Moultray, a well known painter from Dunedin, as war artist, and a Colonel Morris. Neither Kennedy nor Morris actually went to South Africa but provided expert military commentary for opposing papers as the war progressed (All sorts of people, 1901).

Strangely no mention was made in the Otago Daily Times board minutes of James Shand, also appointed by the consortium of papers to accompany Moultray with the 1 st contingent. The Evening Post did, however.

We have despatched two special correspondents (Mr Moultray, of Dunedin, and $\mathrm{Mr}$ Shand, of Auckland) to the scene of operations, with instructions to keep us especially well posted up in the doings of the New Zealand Contingent, and we have no doubt their letters will be looked for with the keenest interest. One of these correspondents is on the troopship Waiwera and the other is travelling in a merchant steamer by way of Australia. We have made other arrangements for securing promptly general news relating to the war, and the Press Association has also engaged a correspondent, so that as far as human foresight can judge the readers of the Evening Post ought to be well served with news. (The Evening Post's war correspondents, 1899, p. 4)

Shand had been a court reporter for the Dunedin Evening Star (Thomas, 1960 , p. 26), and was later to be the chief subeditor of the New Zealand Times (Miller, 1967, p. 40) and editor of the Thames Star (Scholefield, 1958, p. 113). Despite a promise made to his family he would not enlist for World War I, he did so after his two sons were wounded in France. He left his 
daughter to run the Thames Star (Journalists' send-off to soldier confreres, 1915).

The cost of sending correspondents was a big consideration for the New Zealand press. It was expected to be around $£ 500-£ 600$ for all the papers in the consortium. All agreed to pay it. However, all did not go smoothly for the chosen men.

We were somewhat unfortunate in having Mr Moultray as well as our representative with the second contingent being struck down with enteric fever; but Mr J.A. Shand, our second representative with the first contingent, has admittedly done good work although he too was laid aside for a few weeks from the effects of the dreaded enteric. (War correspondents, 1900)

By March 1900 Moultray had been invalided back to New Zealand. He had been attached to Lieutenant-General French's cavalry division in the six months he was in South Africa but after becoming prostrated with fever was warned that a second bout could be fatal (Back from the Front, 1900; Shand, 1900). Some of his sketches of the war were published in the Otago Witness (Moultray, 1900a, 1900b).

The directors of United Press Association considered the possibility of sending a journalist to South Africa but were also concerned about the likely cost. After much discussion the directors decided to appoint Major William Madocks of No 2 Company of the 1 st contingent to act as their correspondent at $£ 3$ a week for one to two columns of news specifically of the New Zealand troops. After seven months this arrangement was rescinded as unsatisfactory. Madocks' despatches arrived late if at all. 'There are now so many correspondents deluging the New Zealand press with letters that there is no necessity for us to continue,' said association manager A. W. Atack, 'especially as they send much later news' (United Press Association minute book, 1899-1900).

According to the New Zealand Free Lance, W. D. Campbell, of the Lyttelton Times, also went to report the South African War but had returned to New Zealand by September 1900 (All sorts of people, 1900). In February of that year The Lyttelton Times and the Otago Daily Times had decided to send a photographer out to the Transvaal and F. B. Hughes was picked for the job (Board of directors minute book 1895-1901), but his work was considered unsatisfactory by Fenwick. In fact Fenwick was generally unhappy with 
the expenses his paper was incurring over war correspondence by the end of 1900 . Not only had the paper spent about $£ 600$ for war correspondence, not including $£ 242$ for the cost of the telegraph services (nearly all despatches were telegraphed), the paper was also paying Major Kennedy for his expert commentary back home and its share of Arthur Adams' despatches from China about the Boxer Rebellion. The end of the war was still not in sight-so much for a short campaign. By the middle of 1900 Fenwick had had enough and demanded that Hughes, Shand and Adams be recalled from their various theatres of war (Fenwick, 1900-1901). Hughes had been a 'severe disappointment, involving a big expenditure for practically nothing', and while he thought Shand's letters were 'full of interest' he suggested in August to W. H. Triggs of The Press that Shand should be recalled as well. 'An occasional letter from one of the other correspondents would probably suffice.' Shand eventually returned in late December 1900 and Hughes in late January 1901. Another possible war correspondent was a Dr Purdie, said by Fenwick, writing to Triggs in January, 1901, to have been appointed as correspondent with the 6th contingent by Gresley Lukin of the Evening Post (Fenwick, 1900-1901).

Shand's work was well received in New Zealand and he was often awarded a byline for his despatches, a rare honour. The New Zealand Free Lance spoke highly of Shand.

Mr Shand of the Thames Star, who has been awarded the African war medal, was an energetic war correspondent who supplied many New Zealand newspapers with 'copy' during the opening stages of the war. Oftentimes, when there was no help for it, Mr Shand was very near the firing line, and whatever happened he was ever most energetic in getting the true points of an engagement from men who were in it. (All sorts of people, 1901, p. 3)

On his return to New Zealand Shand was commissioned to write the official history of the war and this he did but it was never published (Shand, c1931).

One sentence in The Oxford Companion outlined the New Zealand press's contribution to war correspondence in the South African War, usually called the Boer War in the contemporary papers. It only mentioned Shand and Moultray and failed to mention Jewell. Jewell had 'laid up a good deal of experience of the strenuous work of colonisation in Australia before coming to New Zealand' (Untitled, 1910). As Trooper No 149 with the 1st contingent 


\section{REPORTING WARS}

he wrote numerous reports for the Auckland Star. 'His "copy" was written in a bright and breezy style and attracted considerable popular attention and commendation,' said The Observer. They were also remembered for their 'pith and humour' (Untitled, 1907). On his return from the war he went to the literary staff of The Observer, serving at one stage as editor, then transferred to Wellington and became a subeditor on the Free Lance, on the New Zealand Times and then to Taranaki 'to manufacture inky thunderbolts' for the Taranaki Daily News (Untitled, 1911). He returned to Auckland and wrote for the Auckland Star until his death in 1936 (Stowers, 1992). Certainly Jewell and Shand had both established a tradition of war reporting that met the second criteria of the Merriam-Webster dictionary's definition.

\section{The 'Boxer' rebellion 1900}

At the same time as New Zealand soldiers were fighting in South Africa, nations were attempting to quell a rebellion that had broken out in China against foreign influence in that country. Russian troops flooded into China and Manchuria, crushing the rebels, the so-called Boxers. The unrest was at its most intense in 1900 from about early May to the middle of September. New Zealand newspapers at the time called this affray 'the war in China' ('The war in China', 1900).

In June George Fenwick, the managing editor of the Otago Daily Times, received a letter from the editor of The Press wondering whether their papers, along with the Evening Post and the $N Z$ Herald, should send a correspondent to China. If the costs were shared it was thought this might be $£ 100$ each. The Otago Daily Times board agreed (Board of directors minute book 1895-1901). As mentioned previously Arthur Adams, the son of a Dunedin surveyor and nephew of E. T. Gillon, previously of Wellington's Evening Post, was chosen in July as the correspondent. The Oxford Companion does not mention this Chinese conflict as no New Zealand troops were involved.

In October, three months after Adams had left for China, Fenwick was writing to Triggs suggesting that Adams should be recalled 'within reasonable time' (Fenwick, 1900-1901). Fenwick obviously felt the $£ 69.15 .0$ which had already been spent on Adams was sufficient. But Adams was still in China in January 1901, laid up with enteric fever and malaria (Fenwick, 1900-1901). While in China Adams reached Peking and met up with Dr George Morrison, the correspondent of the London Times. He also joined the Victorian contin- 
gent on a 130-mile march into the interior. By the time he returned to Tientsin he had fallen ill and spent two months in bed (Back from China, 1901). He returned to New Zealand on the Mokoia on March 21, 1901. Malcolm Ross interviewed Adams, an old Dunedin friend, as he passed through Wellington on his way south (M. Ross, 1901).

\section{War correspondence between 1902 and 1915}

The next war to be given maximum exposure in daily newspapers round the world but to which no New Zealand journalists appeared to have been sent was the Russo-Japanese War of 1904. At least one newspaper contemplated sending someone. In January the Otago Daily Times considered whether it should send a correspondent and photographer to cover the conflict. Fenwick was willing to spend $£ 250$. As always, he discussed this with his fellow editors on The Press, NZ Herald and Evening Post-now called the New Zealand Associated Press. By mid-February, for reasons not mentioned in the company records, the arrangement fell through (Board of directors minute book 1901-08). Perhaps by this time the expense of sending journalists overseas had finally taken its toll on the newspapers' budgets.

The period between the South African War and the outbreak of World War I was a mirror of what happened between the end of the New Zealand Wars and prior to the troops being sent to the Transvaal. War correspondents came on speaking tours round the country. This time the journalists tended to be Australian rather than British. Among those visiting were Banjo Paterson and Donald Macdonald (Untitled, 1900). Macdonald was said to have made more than $£ 6,000$ on his New Zealand lecture tour and his manager made $£ 2,000$ (A change of tune, 1901). Another visiting war correspondent was Charles Harrison Gibbons, a veteran of the Russo-Japanese War and the SinoJapanese War (All sorts of people, 1907). There did not seem to be so much published about war correspondents in the years between the South African War and 1914 except for extensive coverage of the deaths of William Russell in 1907 (Obituary-Sir William Howard Russell, 1907; Sir William Howard Russell, 1907) and Bennett Burleigh in 1914 (Obituary-Bennett Burleigh, 1914), correspondents who had been lionised in the 19th century.

\section{Last foray of an independent war correspondent}

New Zealand became involved in World War I after Great Britain declared 
war on Germany on August 4, 1914. As evidenced in previous conflicts which concerned the Mother Country, New Zealand was quick to offer her military services. In fact, was one of the first Dominions to do so (Scholefield, 1914). Britain was as equally quick to accept and secretly charged New Zealand forces with capturing German Samoa (Crawford, 2000, p. 174). German Samoa was successfully taken on August 29. The press obviously chafed under the censorship restrictions which forbade them even speculating where the troops may have been sent. A NZ Herald leader bemoaned the 'dense fog which enshrouds every area under the control of the military and naval authorities' (The secrecy of war, 1914). The Governor even had to appeal to the nation to understand the need for secrecy and not spread rumours about the destination of the New Zealand Expeditionary Force (Movements of forces, 1914). Official acknowledgment of the action was finally received by the New Zealand public via London on Monday afternoon August 31 in the Evening Post and by the NZ Herald and Otago Daily Times the next morning (Samoa and the war, 1914; Untitled, 1914).

When the two troopships had set forth on August 15, on board one of them, Troopship No 1, the Monowai, was Malcolm Ross. At the last minute, he had made arrangements to go with the troops with the commandant of the New Zealand forces, General Alexander Godley. Ross had obviously informed either Fenwick or Triggs of what was happening before he left, because the minutes of the Otago Daily Times board on August 21, while Ross was sailing to Samoa, said that arrangements had been made with him to leave New Zealand with the 1st NZEF as special correspondent for the Otago Daily Times, The Press, The Dominion and NZ Herald with the salary to be $£ 8$ per week plus expenses of $£ 10$ towards photographic equipment. Ross was expected to be absent about two months (Board of directors minute book 1908-1917). He was only away for three weeks. The Oxford companion said Ross was 'recalled', but does not say by whom or why.

His first despatch did not get published in the New Zealand papers until a day after his return on September 7. Ross wrote four very long narrative pieces for the Otago Daily Times (M. Ross, 1914a, 1914c, 1914d, 1914e), parts of which were also published in The Press and $N Z$ Herald and other papers. He also submitted an official report to the Government on the taking of Samoa and this was forwarded to the Press Association (M. Ross, 1914b). He even found time to write a one-and-a-half-column article for The New York Times 
which was sent from Wellington on September 19 and bylined 'by Malcolm Ross FRGS, special correspondent of The New York Times' (M. Ross, 1914f). The Oxford Companion mentions Ross's role in this campaign, albeit briefly (p. 578). His work aroused a political hornets' nest on publication. The rivalry between political parties and their respective newspapers erupted in Parliament when it was learned that Ross had stolen his journalistic confreres' thunder by accompanying the NZEF to Samoa.

At the same time as the NZEF was preparing to set out for Samoa, the New Zealand Government was being informed by the Secretary of State for the Colonies dated August 12 that if it so desired one war correspondent, representing the whole press of the country, could accompany the British Forces in the field, such correspondent being subject to military regulations (NZ Parliamentary Debates: Expeditionary force: War correspondent 1914). The focus now turned to which New Zealand journalist was going to get the job, how he was going to get it, who would pay him and for whom he would be writing. Whereas before it had been a decision made by individual newspapers whether to send journalists to cover conflicts, this time it was to be a different story. One journalist alone was to go and whoever it was, he was going to be a servant of the government, and by association, of the military authorities, and not any individual newspaper. A new tradition of war correspondence was about to commence, one where the government paid for the correspondent not the nation's newspapers as in the past.

\section{Conclusion}

The purpose of this study is to demonstrate that New Zealand newspapers up to 1915 had established a tradition of war correspondence by sending journalists to conflicts they described as wars. This refutes the suggestion in The Oxford Companion that this had not occurred prior to World War I. In the sense of tradition as defined by the Merriam-Webster dictionary, it is clear from the newspaper coverage that the work of various war correspondents was recorded and remembered long after the wars being reported on had occurred. While there may be debate over whether the conflicts mentioned would be called 'wars' today, it was clear the newspapers called them 'wars" and sent their reporters to them as "war correspondents'.

If newspapers had no wars to which they sent correspondents they certainly kept abreast of what other war correspondents were doing abroad. Up to and 
including the South African War it seems clear that war correspondents were as much news as the events they covered. British journalists such as Russell, Forbes, Burleigh and Steevens were household names in New Zealand and their 'adventures' were covered regularly and in detail and their deaths recorded in the same way. Perhaps the New Zealand journalists saw themselves building on this older, British tradition of war correspondence.

Those men who reported wars usually did so as an adjunct to their normal work, not as professional war correspondents. Quite often they were soldier journalists, such as Woon, Montrose and Jewell. Because of the cost, many New Zealand newspapers joined forces to send journalists overseas. The most significant syndicate included four of the most powerful papers in the country-the NZ Herald, The Press, the Otago Daily Times and The Evening Post collectively called the New Zealand Associated Press. For the overseas wars, papers did not expect to have their journalists away for any length of time and usually withdrew them early because of the expense of maintaining them abroad. They then had to arrange other means of informing their readers.

Before World War I reporting of war by New Zealand journalists had not been sponsored by the state. On the contrary, as demonstrated, it was the newspapers that assigned war correspondents to cover wars in New Zealand, Samoa, South Africa and China. The tradition is much richer than first thought. However, there have been obstacles to obtaining more information. There is a dearth of primary material available for study. Apart from the Otago Daily Times, few newspapers have made their early records available for research. There is little information to indicate how the early New Zealand pioneers of war reporting worked, whether they were censored and whether their movements were restricted by the military. It does appear the correspondents were largely free to get near the front and report the action and with little censorship. The military seemed relatively accommodating. However, more research is needed to discover whether this was, in fact, true. World War I saw many changes and this freedom granted the correspondents in earlier wars was to be severely curtailed after 1914 .

\section{References}

All sorts of people. (1900, September 15). New Zealand Free Lance, p. 3. All sorts of people. (1901, December 7). New Zealand Free Lance, p. 3. All Sorts of People. (1907, September 14). New Zealand Free Lance, p. 4. Archibald Forbes in New Zealand. (1882, November 29). Hawera and Normanby Star, p. 2. 
Back from China. (1901, March 22). Evening Post, p. 6.

Back from the Front-a war correspondent in Wellington. (1900, March 6). Evening Post, p. 5.

Barclay, G. (1978). A history of the Pacific-from the Stone Age to the present day. London: Sidgwick \& Jackson.

Board of directors minute book 1895-1901. Otago Daily Times \& Witness newspaper records AG 632 2/3. Hocken Library, Dunedin.

Board of directors minute book 1901-1908. Otago Daily Times \& Witness newspaper records AG 632 2/4. Hocken Library, Dunedin.

Board of directors minute book 1908-1917. Otago Daily Times \& Witness newspaper records AG 632 2/5. Hocken Library, Dunedin.

A brave correspondent (1877, November 3). Otago Witness, p. 7.

A celebrated war correspondent-an interview with $\mathrm{Mr}$ Phil Robinson. (1888 November 30). Otago Witness, p. 8.

A change of tune-praise from an unexpected quarter. (1901, February 9). The Observer, p. 7.

Crawford, J. (2000). The Oxford companion to New Zealand military history. In I. McGibbon (Ed.), The Oxford companion to New Zealand military history (pp. 59-63). Auckland: OUP.

Dictionary of Australian biography. Retrieved on 5 February 2010 from http://gutenberg.net.au/dictbiog/0-dict-biogWe-Wy.html

An eminent war correspondent (1878, January 12). Evening Post, , p. 1.

English notes. (1871, May 20). Otago Witness, p. 4.

European summary. (1881, May 30). Evening Post, p. 2.

The Evening Post's war correspondents. (1899, October 28). Evening Post, p. 4.

Experiences of a war correspondent. (1888, December 22). Evening Post, p. 2.

Featon, J. (1879). The Waikato War, 1863-4. Auckland: J. Wickham.

Fenwick, G. Letter book 1899-1902. Otago Daily Times \& Witness newspaper records AG 632 4/5, Hocken Library, Dunedin.

Fenwick, G. Letter book 1900-1901. Otago Daily Times \& Witness newspaper records AG 632 4/6, Hocken Library, Dunedin.

A great war correspondent. (1895, August 24). Hawera \& Normanby Star, p. 2. Hatton, J. (1885, April 4). A chat with George Augustus Sala. Otago Witness, p. 25. An interview with Mr Phil Robinson. (1888, November 29). Evening Post, p. 4. Is the war correspondent doomed? (1904, August 18). Otago Daily Times, p. 6. Journalists' send-off to soldier confreres. (1915, December 11). Wellington: Blundell Brothers. p. 7.

Judicial separation-Phil Robinson and his wife. (1889, June 1). Te Aroha News, p. 5. Local and general. (1883, June 23). Otago Witness, p. 8.

Looking at war. (1890, February 27). Otago Witness, p. 34.

Lovelace, C. (1978). British press censorship during the First World War-Part Two. In G. Boyce, J. Curran \& P. Wingate (Eds.), Newspaper history: From the 17th century to the present day. London: Constable. 
McGibbon, I. (2003). 'Something of them is here recorded': Official history in New Zealand. In J. G. Greg (Ed.), The official history of New Zealand in the Second World War 1939-1945. Westport Praeger Publishers

McGibbon, I. (Ed.). (2000). The Oxford companion to New Zealand military history. Auckland: Oxford University Press.

The Māori War-The loyal Wanganui natives' secret expedition. (1868, December 5). Star, p.3.

The Māori Wars-von Tempsky's career. (1906, July 21). New Zealand Truth, p. 7. Merriam-Webster dictionary online. (2007). Retrieved on 7 October 2007, from www.m-w.com/cgi-bin/netdict?tradition

Miller, F. W. G. (1967). Ink on my fingers. Wellington: A H \& A W Reed.

More pressmen arrested-they will be tried as spies. (1898, June 2). Evening Post, p. 5. Morris, N. (Ed.). (1963). The journal of William Morgan: Pioneer settler and Māori war correspondent (Reprint 1999 ed.). Christchurch: Cadsonbury.

Moultray, J. E. (1900a, 1900, January 11). Sketches of the Transvaal war. Otago Witness, p. 33.

Moultray, J. E. (1900b, 5 April 1900). Untitled. Otago Witness, p. 35.

Movements of forces-the need for secrecy-appeal by Governor. (1914, August 29). New Zealand Herald, p. 9.

Mr David Christie Murray-Looking at war. (1890, April 2). Evening Post, p. 2.

Mr Howard Vincent. (1884, October 11). Evening Post, p. 2.

Mr Villiers on New Zealand. (1895, September 24). Evening Post, p. 2.

NZ Parliamentary Debates: Expeditionary force: War correspondent (1914). (Vol. 171). Wellington: NZ Government.

Obituary-Bennett Burleigh. (1914, June 18). Evening Post, p. 7.

Obituary-Sir William Howard Russell. (1907, February 12). Evening Post, p. 7.

Obituary-F. Carr Rollett. (1931, December 23). Auckland Star.

Oosterman, A. (2008). Malcolm Ross and the Samoan 'troubles' of 1899. Pacific Journalism Review. 14(2), 163-182.

Our public men. (1878, August 12). North Otago Times, p. 2.

Passing notes. (1885, October 3). Otago Witness, p. 17.

Phil Robinson's divorce case. (1889, August 3). Evening Post, p. 2.

Phil Robinson and his troubles. (1889, July 31). Evening Post, p. 2.

Ross, A. (1964). New Zealand aspirations in the Pacific in the 19th century. Oxford: Clarendon Press

Ross, M. (1899c, February 15). The crisis in Samoa-a state of anarchy-scenes of the war-the British navy insulted. The Press, pp. 5-6.

Ross, M. (1899e, February 15). The Samoan crisis-a state of anarchy and dissatisfaction-extraordinary actions of the president and provisional Government. Otago Daily Times, p. 4.

Ross, M. (1901, March 27). Back from China-interview with a war correspondent. Otago Witness, p. 71.

Ross, M. (1914a, September 10). Capture of Samoa-by New Zealand expeditionary Force-No 3. Otago Daily Times, p. 6. 
Ross, M. (1914b, August 8). The capture of Samoa-the official report. Otago Daily Times, p. 7.

Ross, M. (1914c, September 8). The capture of Samoa by New Zealand Expeditionary Force - No 1. Otago Daily Times, p. 7.

Ross, M. (1914d, September 9). Capture of Samoa by New Zealand Expeditionary Force - No 2. Otago Daily Times, p. 2.

Ross, M. (1914e, September 11). Capture of Samoa by New Zealand Expeditionary Force - No 4. Otago Daily Times, p. 2.

Ross, M. (1914f, September 21). Samoa was taken without a struggle. The New York Times, p. 4.

Russell, W. H. (1855). The war-from the landing at Gallipoli to the death of Lord Raglan (First ed.). London: George Routledge \& Co.

Sala, G. A. (1885, August 1). The traveller-the land of the golden fleece. Otago Witness, p. 18.

The Samoan situation. (1899, April 1). Evening Post, p. 6.

The Samoan war-attitude of the powers-office for service from New ZealandAuckland volunteers enrolling.(1899, April 3). The Press, p. 5.

The Samoan war-sharp fighting with the rebels. (1899, May 10). Otago Daily Times, p. 6.

Scholefield, G. H. (1914, September 20). New Zealand's help-first offered. New Zealand Herald, p. 9.

Scholefield, G. H. (1958). Newspapers in New Zealand. Wellington: A.H. \& A.W. Reed.

The secrecy of war. (1914 August 22). New Zealand Herald, p. 6.

Shand, J. A. (1900, February 15). With our contingent. Otago Witness, p. 67.

Shand, J. A. (c1931). O'er veldt and kopje: The official account of the operations of the New Zealand contingents in the Boer War. MS-1780-1793. Wellington: Alexander Turnbull Library.

Sir William Howard Russell. (1907, July 24). Otago Witness, p. 79.

The Stanley lectures-'How I found Livingstone'. (1892, January 7). Evening Post, p. 2.

Stowers, R. (1992). Kiwi versus Boer. Hamilton: Richard Stowers.

Thomas, W. H. (1960). The inky way-by Nonagenarian. Auckland: Clark \& Matheson.

United Press Association minute book. (1899-1900). United Press Association.

Untitled. (1899a, October 9). Auckland Star, p. 4.

Untitled. (1899b, November 18). The Observer, p. 6.

Untitled. (1900, December 15). The Observer, p. 6.

Untitled. (1903, February 21). New Zealand Free Lance, p. 3.

Untitled. (1907, August 17). The Observer, p. 5.

Untitled. (1910, January 15). The Observer, p. 5.

Untitled. (1911, September 30). The Observer, p. 4.

Untitled. (1914, September 1). Otago Daily Times, p. 5. 


\title{
REPORTING WARS
}

Untitled. (1915, February 3). New Zealand Free Lance, p. 10. War correspondents. (1900, August 28). Otago Daily Times.

The war in China. (1900, July 26). Otago Witness, p. 23.

Ward, A. W., Waller, A.R., Trent, W.P., Erskine, J., Sherman, S.P. \&. Van Doren, C. (Ed.). (1907-1921). The Cambridge history of English and American literature in 18 volumes (1907-21). (Vol. Volume XIV. The Victorian age, Part two.). New York, Cambridge: G.P. Putnam's Sons, University Press. Retrieved on 10 December 2008 from www.bartleby.com/br/211.html

Dr Allison Oosterman is a senior lecturer in AUT University's School of Communication Studies. This article is drawn from her doctoral research about the career of Malcolm Ross, New Zealand's first official war correspondent in World War 1. An earlier version was presented at the Journalism Education Association of New Zealand (JEANZ) conference in Wellington in December 2007. aoosterm@aut.ac.nz

\section{TIMARU 2010}

Journalism Education Association of New Zealand Annual Conference, 2 and 3 December

\section{Theme:What Editors Want}

\begin{abstract}
Partners programme being developed for those who wish to use the conference as the launch for a holiday in the Mainland.
\end{abstract}

There are flights directly into Timaru from Wellington. Alternatively, fly to Christchurch and drive (two hours).

The JEANZ AGM will be held on 3 December

Convenor: Peter O'Neill Ph: +64 36840845 Email: peter.oneill@aoraki.ac.nz

Abstracts: Jim Tully Ph: +643 364288। Email: jim.tully@canterbury.ac.nz

Registration: Janine Burgess Ph: +6436848240 Email: janine.burgess@aoraki.ac.nz 
Copyright of Pacific Journalism Review is the property of Auckland University of Technology and its content may not be copied or emailed to multiple sites or posted to a listserv without the copyright holder's express written permission. However, users may print, download, or email articles for individual use.

http://www.aut.ac.nz/depts/commstud/journ/pjrsubs.shtml 